UDC 72.007(01)

https://doi.org/10.51488/1680-080X/2021.4-15

IRSTI 67.25.

\author{
G.S. Abdrassilova ${ }^{1}$, L.M. Aukhadiyeva ${ }^{1^{*}}$ \\ ${ }^{1}$ International Educational Corporation (KazGASA campus)
}

Information about authors:

Abdrassilova Gulnar - Doctor of Archecture, Acad. Prof. of Architecture Faculty, International Educational Corporation (KazGASA campus)

https://orcid.org/0000-0002-3828-9220, e-mail: g.abdrassilova@kazgasa.kz

Aukhadiyeva Laura - Doctoral student, International Educational Corporation (KazGASA campus), Almaty,

Kazakhstan

https://orcid.org/0000-0002-8834-3141, e-mail: laukhadiyeva@gmail.com

\title{
SAKEN NARYNOV'S ARTWORKS: THE SYMBIOSIS OF ARCHITECTURE AND TOPOLOGICAL EXPERIMENTS
}

Annotation. The works of Kazakh architect Saken Narynov attract researchers from various countries due to their innovative features. His works divided into three groups: topological experiments; public and residential buildings; futuristic projects. The article is based on the study of scientific papers, conversations with the architect, as well as design and graphic documents from the master's archive. The analysis S. Narynov's works allows to identify new directions in the modern regional architecture of Kazakhstan.

Keywords: Architect Saken Narynov, regional architecture, architecture of Kazakhstan, regional identity, topological forms.

\section{Introduction}

On October 16, 2021, the famous Kazakhstan architect Saken Narynov turned 75. Tireless in his creative search, for almost half a century, S. Narynov has developed over 100 architectural projects, received 5 inventor's certificates, participates in international competitions and exhibitions, and gives lectures in Russia and Kazakhstan.

After graduating from the architectural faculty of Kazakh Polytechnic Institute (now the Faculty of Architecture of KazGASA) in 1970, he continued his studies as a postgraduate student of Kazakh Leading Academy of Architecture and Civil Engineering and in the advanced training courses at Moscow Architectural Institute (MARKHI). For several years, he taught at the Department of Theory and History of Architecture of KazGASA. But in 2002, following his strong desire to experiment with form and space, he founded the Kopkyrly ("Multifaceted") workshop in Almaty, where he still works. S. Narynov is a cavalier of the Kurmet order, Honorary architect of Kazakhstan, and professor of KazGASA.

\section{Materials and methods}

The conclusions of the article are based on the analysis of design, graphic, photos, and video materials from the archive of S. Narynov, scientific papers dedicated to the master's works, and materials of conversations with the architect. 


\section{Results and disccusion}

He began his architectural activities in the last quarter of the XX century, in the XXI century researcher and experimenter Saken Narynov demonstrates creative maturity, combining local traditions of nomadic culture and scientific achievements into a single regional image, and creates the brand-new conceptual designs of the architecture of Kazakhstan. Early works of the architect were aimed at solving the practical as well as design and technical tasks of architecture: the projects of mobile houses for hot climate conditions; dismountable facilities with the use of separable rigid pipe joints (an inventor's certificate was obtained) [2].

Creative ideas for Saken Narynov's projects originate from his childhood when his grandparents told him folk tales that gave birth to bizarre fantasies in the boy's mind. As a teenager, Saken spent hours reading books, which transformed his vision of the world from a conceptual polysemantic microcosm into a cosmic one. But the wish to look beyond the profession and the thirst for knowledge led the young researcher to the papers of Stephen Hawking, American engineer R. Buckminster Fuller, Japanese architect Kisho Kurokawa, philosopher Mikhail Bakhtin, Moebius strip, stories of Bruce Elliott, etc.

S. Narynov found the confirmation of some of his ideas in the works of the Dutch artist (who had an architectural education) Maurits Escher, who introduced the plastic aspects of the concepts of "infinity" and "symmetry" into his works and relied on the peculiarities of psychological perception of complex three-dimensional objects. Being a prominent representative of impossibilism, M. Escher has developed specific methods of graphical constructions of spatial transformations, creating incredible optical illusions.

Being interested in Einstein's theory of relativity, scientific search in the field of the relationship between space and time, S. Narynov carries out his topological experiments. Einstein's student Martin Gardner, with whom the architect corresponded, wrote to S. Narynov: "You looked so far as no one else did..." [2].

Topological forms of S. Narynov are special artistic and monumental sculptures, in which the author reflects his vision of creation and development of the world, from a molecule to the universe. In his invention called the Kazakh bottle by analogy with the Klein bottle phenomenon, the author expressed the infinity of flowing space. Kazakh bottle occupies a central place in S. Narynov's exposition "In Time and Space" (Fig.1).
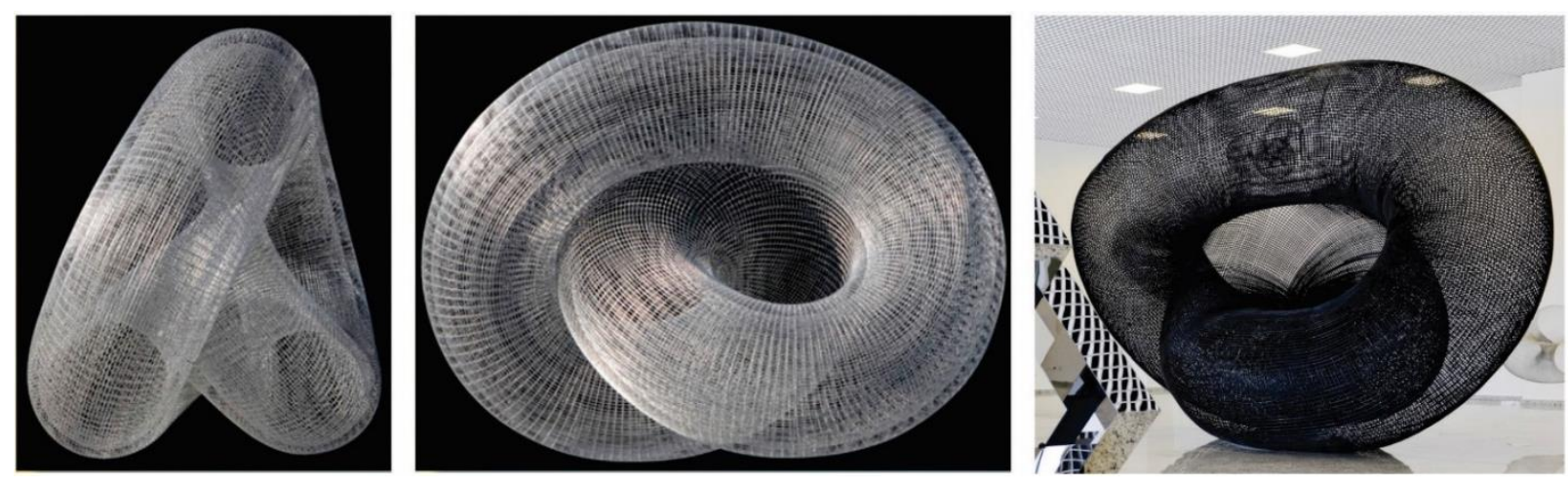

Figure 1 - Kazakh bottle, 1989 [2] 
In his projects, Saken Narynov shows a deep understanding of symbolic elements of architecture.

The ALZHIR (Akmola camp of the wives of betrayers of the nation, 2007) museum and memorial complex of political repressions and totalitarianism victims is located in the village of Akmol, Tselinograd district of Akmola region. In this project full of symbols, the author reflected the pain and sufferings of the victims of Stalin's repressions. The museum complex includes the museum building, the monument "Arch of Sorrow", and sculptural compositions "Struggle and Hope", "Despair and Strengthlessness" and "Memory Wall". The author intended this project to be a tribute to the generations of the 1930s through immersion in the atmosphere of camp life. Unfortunately, not all ideas of the author were implemented in the course of construction (Fig.2) [3].

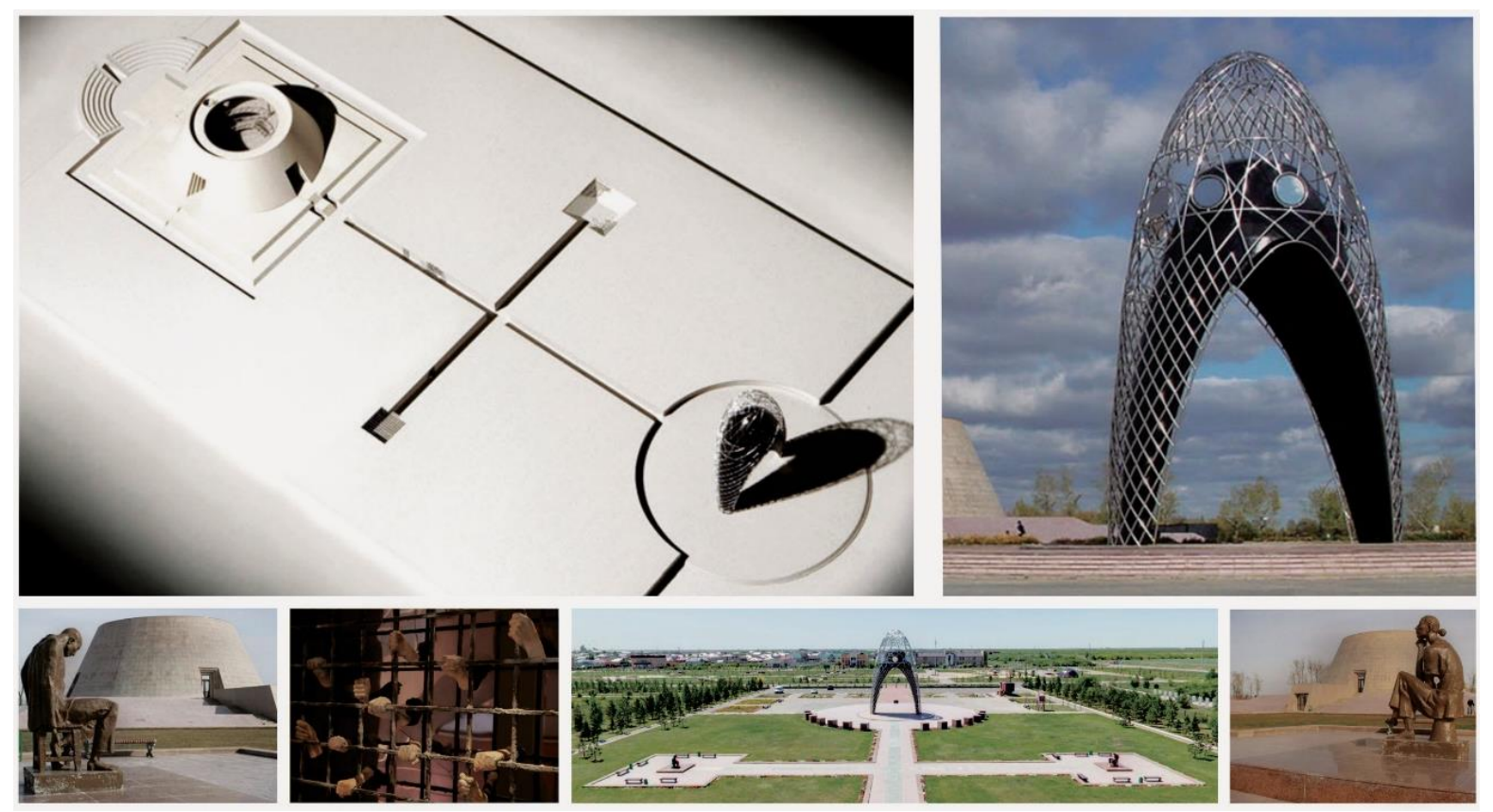

Figure 2 - ALZHIR museum and memorial complex of political repressions and totalitarianism victims, 2007 [2]

In his projects, the architect identifies architecture with the culture and traditions of Kazakhstan, where traditional construction materials are used and the local building methods are revived. He considers freedom, which is reflected in the attitude of nomads to space, one of the key values of nomadic culture. He vividly demonstrates the influence of forms on space [3].

The philosophic nature of thoughts about regional identity was reflected in the projects of clay dwellings: Kyzylorda region (1991); the topic of the competition of the Earth projects, Osaka (1991); private house in Almaty (2006); competition project of a health complex in Shymkent (2006); competition project, cellular multi-family clay settlement (2005), etc. In 2008-2009, conceptual designs of the architect gained worldwide recognition on the World Architecture Community platform, which unites specialists from 120 countries. The community included the works of Saken Narynov in the list of the world's 20 best projects [2]. 


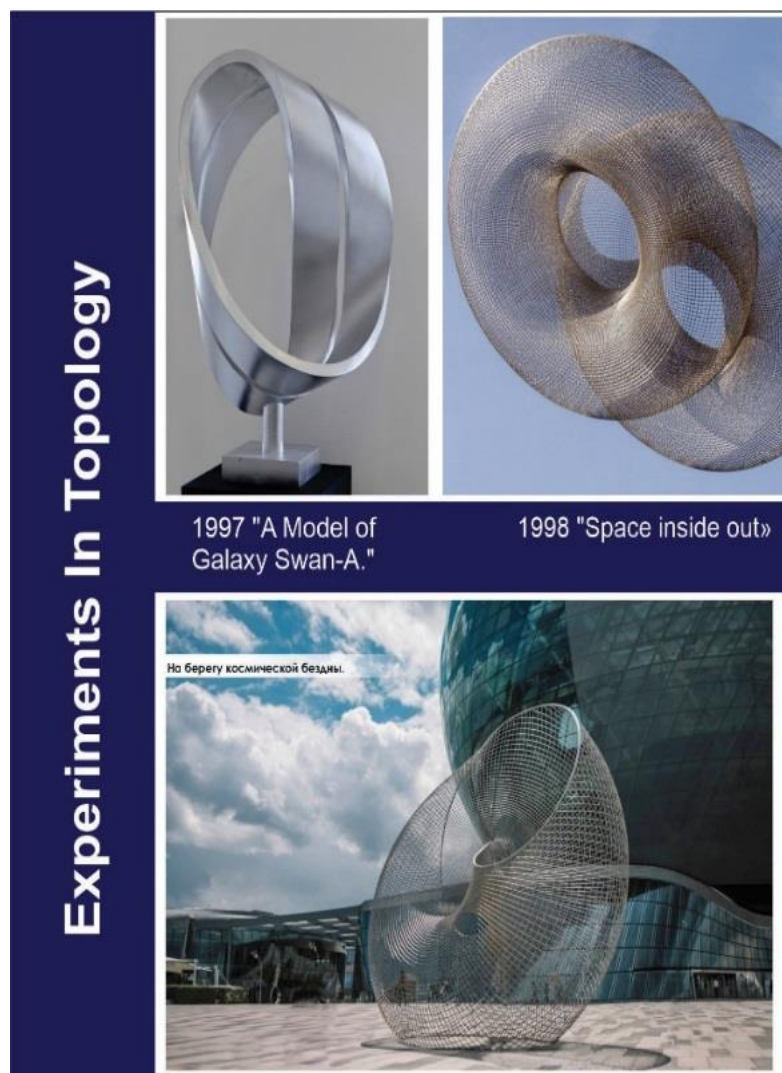

2017 EXPO Astana "On the shore of the space abyss"
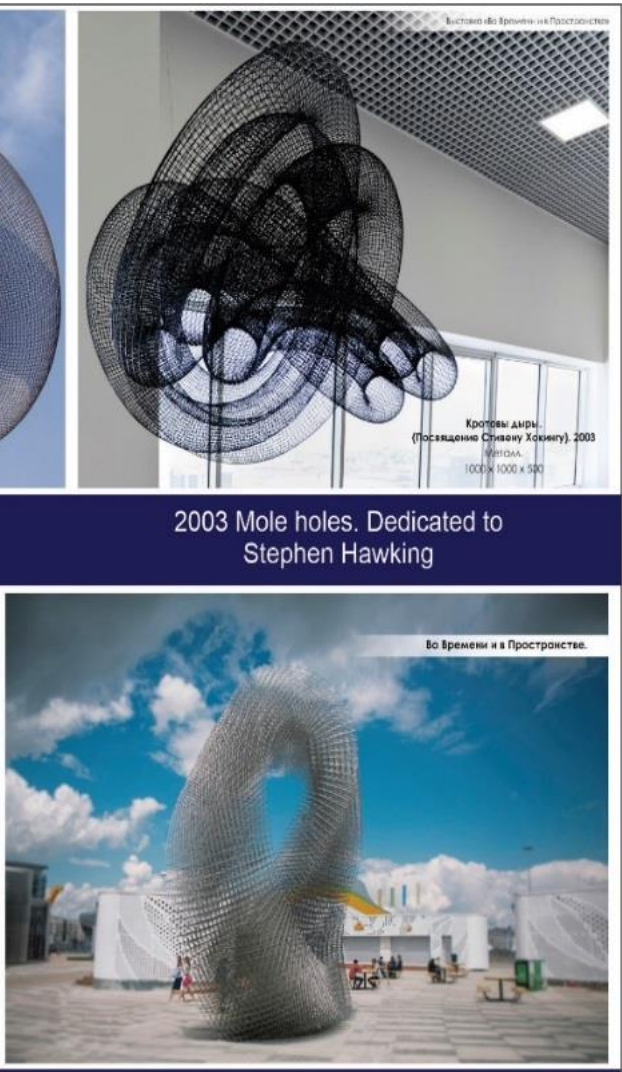

2017 EXPO Astana "In time andspace "
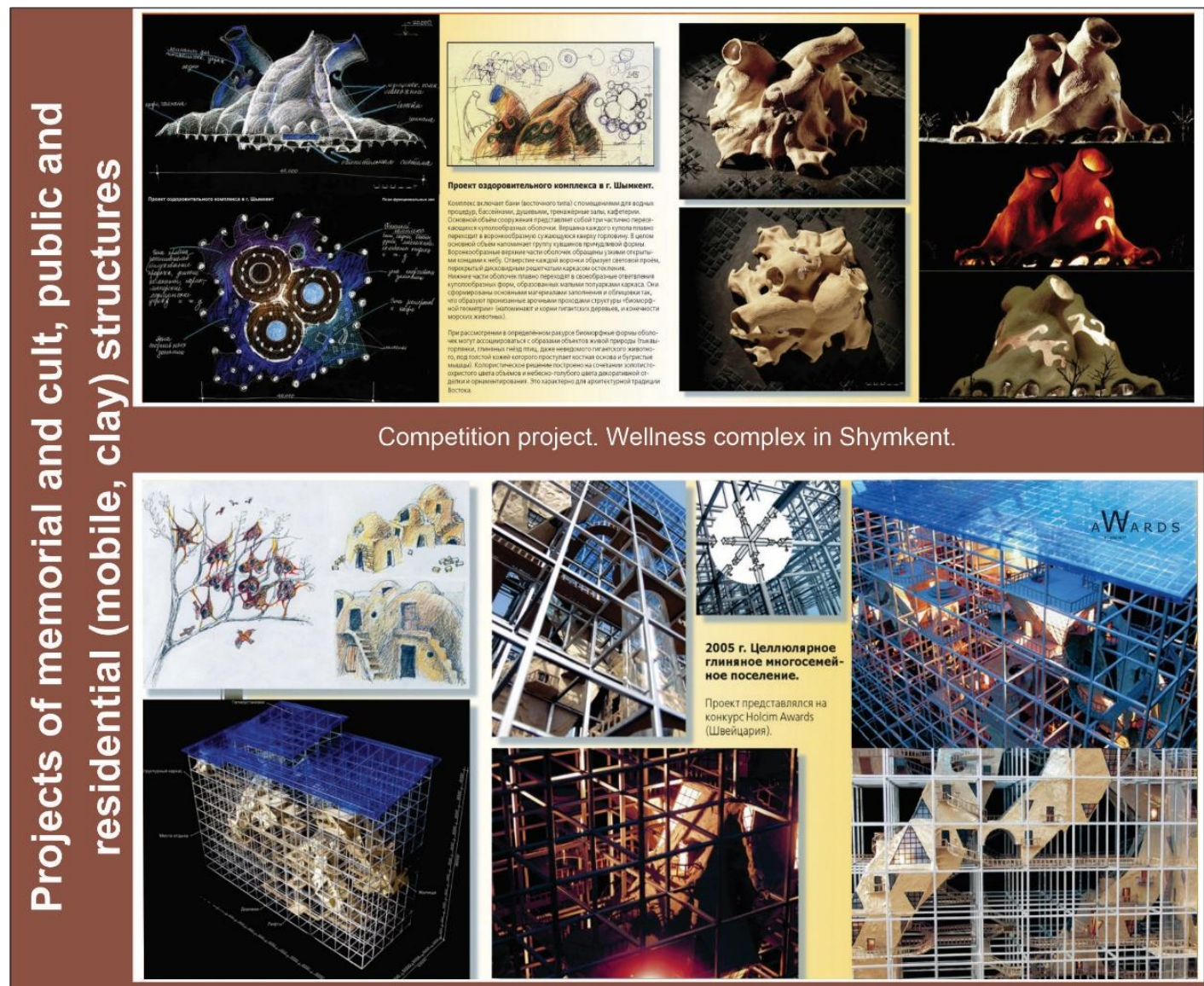

Competition project. Wellness complex in Shymkent.

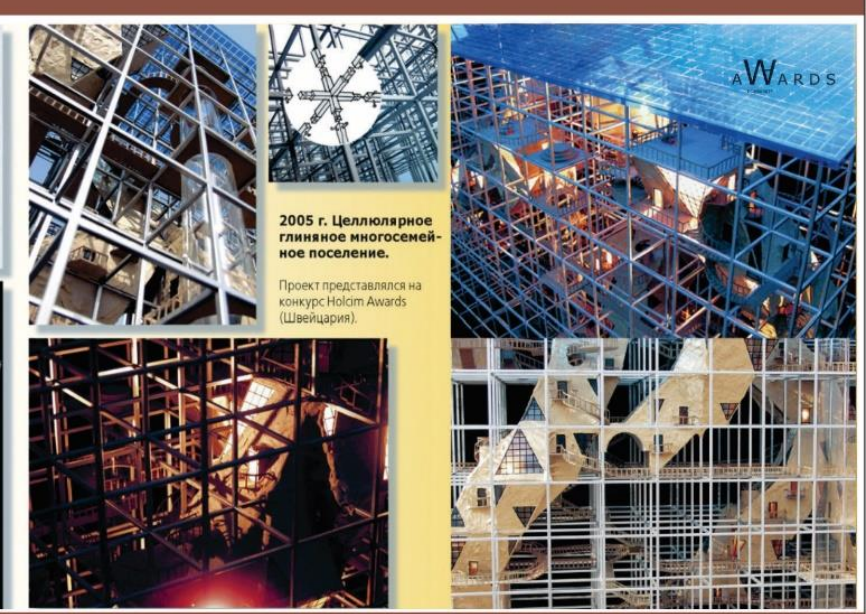

Competition project, cellular clay multifamily settlement 


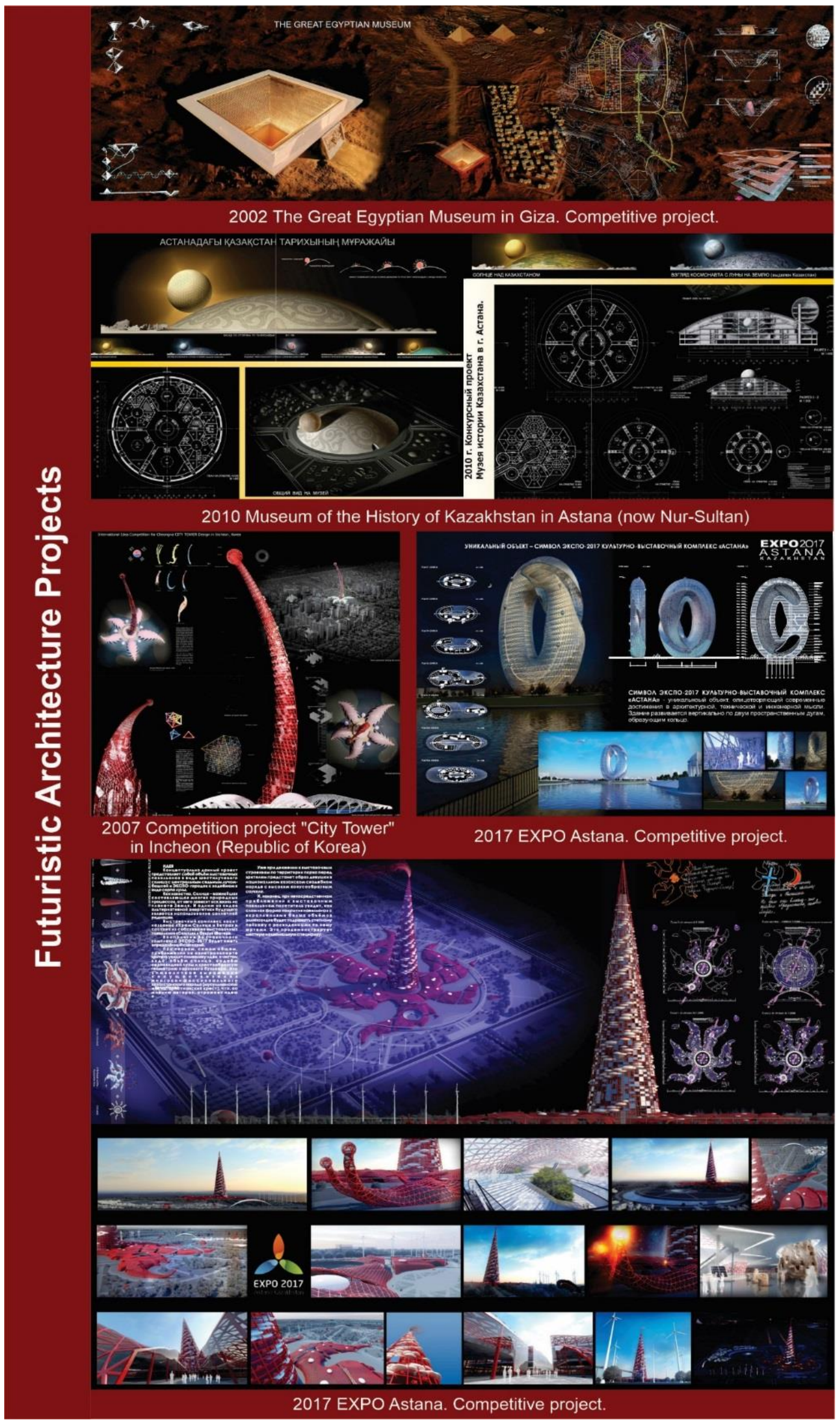

Figure 3 - Competitive projects [3] 
Artistic and architectural projects of S. Narynov took part in competitions and were exhibited at national and international exhibitions - in Moscow (Russia, 19851999, 2002, 2008), Plovdiv (Bulgaria, 1985), Ashgabat (Turkmenistan, 1992), Osaka (Japan, 1991), Berlin (Germany, 1994), Lyon (France, 1995), Lima (Peru, 1995), Copenhagen (Denmark, 1998), Almaty, Astana, Kokshetau (Kazakhstan, 2000), Istanbul (Turkey, 2010), London (Great Britain, 2011), Dubai (UAE, 2013), etc. The architect has such awards as "Dwelling of the future", Moscow $-1^{\text {st }}$ place; "Ecodwelling" - Almaty $-2^{\text {nd }}$ place; "Earth", Osaka, Japan - entered in the list of the world's 20 best projects; "Beautiful house", Italy - incentive award; "Mobile dwelling", Peru - approval; Denmark - recognition and approval. The variety of the architect's experimental projects reflects the interdisciplinarity of approaches as a basis of the author's style. A. Ikonnikov noted the particular complexity of the intermediate (between material and artistic) position of the architect who "is constantly dealing with various information and must combine different types of professional consciousness and activities in his creative method" [1, p. 7].

The implemented projects of the architect include two large sculptures "On the shore of the Cosmic Sea and parallel words" at the Astana EXPO-2017 exhibition.

Saken Narynov's works are experiments with the form as a way of interaction in the environment, which brings a sense of transformation of the Form in Space by the Contemplator himself. His projects can be divided into three groups: topological experiments, projects of memorial and cult, public, and residential (mobile, clay) buildings and futuristic projects (Fig.3) [3].

\section{Results and discussion}

Despite the avant-garde nature of his works, S. Narynov's philosophy comes from his own identity: in his search, he relies not only on universal signs of architecture but on regional peculiarities as well. Like any creative person, the architect is looking for the origins of his own concepts, and in a personal conversation with the authors of this article, he expressed the following opinion: "Genetic engineering, which forms human characteristics, as an ancient foundation, has always been present in me. When I say "genetic engineering", I mean that something seems to be given to every person from heaven. That's what my mother said. And this, perhaps, was the beginning of my search. ... I think that every people some kind of, maybe, not a program, but something that is inherent in it: since a person lives in a certain environment, he is influenced by folk tales, myths, smell, color, and space of this land. Probably, all this formed the beginning of all my beginnings".

To the questions of how he manages to create projects that are ahead of time in terms of technology and concept, S. Narynov answers: “... the architect who focuses only on the rules and standards of design can hardly achieve something in creativity event with a brilliant sense of rhythm, understanding of the rules of shaping in architecture, and other knowledge available to him. I think we should read a lot; of 
course, it depends on the enthusiasm of each architect. I can say that literature has made me a person ... has cultivated not only an understanding of the art but also the desire to express the spirit of my works".

Talking about the influence of nomadic culture on the modern culture of Kazakhstan, S. Narynov always stresses that he is not a supporter of "visible architecture, in which everything is predetermined, in which explicit forms of arches and domes are used".

Matured 75-year-old master is still astonished at the diversity of the world and surprises the world with its works. In his lectures for young architects, he calls on them to learn the depths of their own culture and study world scientific achievements, understand the origins of the nomadic civilization of the ancestors, and link it with modern engineering and technological advances. But in the center of his creative concepts, S. Narynov puts the Human with his passions, problems, wide interests, love for music, poetry, nature, and curiosity about the world around him. Human is the only bearer of culture. "Once I gave up everything and started reading Stephen Hawking," S Narynov tells, "and I still wonder: why does space go into time, and vice versa? An architect should always ask himself not only specific questions, such as "how to build a staircase?" He should desire to solve some unsolvable problems, create something new, unique".

It was a strong desire to understand the amazing secrets of space and time that formed a specific style of S. Narynov - a symbiosis of architecture and topological forms. They constitute two inseparable parts of a creative concept, enrich and supplement each other, and bring a unique color to the modern architecture and arts of Kazakhstan. It is the architecture that creates a sense of the reality of topological forms, and it is topological experiments that give S. Narynov's architecture a futuristic nature and power.

\section{Conclusion}

Saken Narynov is an architect and experimenter working both in the fields of designing buildings and facilities and artistic experiments. His projects can be divided into three groups: topological experiments, projects of memorial and religious, public, and residential (mobile, clay) buildings, and futuristic projects. The main source of regional identity is historical heritage, especially valuable in the architect's works, which include ancient (clay dwellings) and modern history (competition project of EXPO-2017 in Nur-Sultan).

The architect sees the origins of his design ideas in the study of the culture and traditions of Kazakhstan and learning the world's scientific theories in the fields of mathematics, physics, geometry, philosophy, graphics, etc. The achievements of S. Narynov are confirmed by numerous international awards, implemented projects, and participation in art exhibitions in various countries.

The analysis of S. Narynov's projects established that focusing on different aspects leads to the emergence of various strategies in regional architecture, in particular: 
- inspiration by local nature;

- use of historical images / pictures;

- creative use of traditional materials;

- everything that characterizes culture, for example, even fairy tales and myths.

Despite the avant-garde nature of his works, S. Narynov's philosophy comes from his own identity: in his search, he relies not only on universal signs of architecture but on regional peculiarities as well.

All works of S. Narynov have an inextricable link between material architectural shaping and bold topological experiments. The study of the creative origins and achievements of architect Saken Narynov allows to reveal different facets of his artistic and design activities aimed at transforming our reality.

\section{References:}

1. Ikonnikov AV (1986) Function, form, and image in architecture [Funktsiya, forma, obraz v arkhitekture]. M.: Stroyizdat, 288. (in Russ.)

2. Lichnyj arhiv arhitektora Sakena Narynova [Private archive of the architect Saken Narynov] (in Russ.)

3. Abdrasilova G.S. Traditsii $i$ novatorstvo v arkhitekturnom tvorchestve Sakena Narynova [Traditions and innovations in the architectural works of Saken Narynov]. Nauchnye trudy SWorld =Collection of scientific papers SWorld. 2014, 2(16), 38-44. (in Russ.)

4. Magiya arkhitektury Sakena Narynova [Magic of Saken Narynov's architecture]. [Electronic sources] - URL: https://hubspeakers.ru/bio/narynov

5. The World Architecture Community. [Electronic sources] - URL: https://worldarchitecture.org/architecture-projects/emgn/saken-narynov-s-top-art--projectpages.html. (in Russ.)

6. Muzeyno-memorial'nyy kompleks zhertv repressiy i totalitarizma «ALZHIR» [Website of the ALZHIR museum and memorial complex of political repressions and totalitarianism victims] [Electronic sources] - URL: https://museum-alzhir.kz/ru/. (in Russ.)

7. Materialy chastnyh besed avtorov stat'i s arhitektorom Sakenom Narynovym [Materials of private conversations of the authors of the article with the architect Saken Narynov] (in Russ.)

\section{Г.С Абдрасилова ${ }^{1}$, Л.М. Аухадиева ${ }^{*}$}

${ }^{1}$ Халықаралық білім беру корпорациясы (КазБСҚА кампусы), Алматы, Қазақстан

\section{Авторлар жайлы ақпарат:}

Абдрасилова Гульнар Сейдахметовна - сәулет докторы, Сәулет факультетінің академиялық профессоры, Халықаралық білім беру корпорация (КазБСҚА кампусы), Алматы, Казахстан

https://orcid.org/0000-0002-3828-9220, e-mail: g.abdrassilova@kazgasa.kz

Аухадиева Лаура Мукановна - сәулет факультетінің докторанты, Халықаралық білім беру корпорация (КазБСҚА кампусы), Алматы, Казахстан

https://orcid.org/0000-0002-8834-3141, e-mail: laukhadiyeva@gmail.com 


\title{
СӘКЕН НАРЫНОВ ӨНЕРІ: СӘУЛЕТ ПЕН ТОПОЛОГИЯЛЫҚ ЭКСПЕРИМЕНТТЕРДІН СИМБИОЗЫ
}

\begin{abstract}
Андатпа. Қазақсстандық сәулетші Сәкен Нарыновтың шывармашылывы жаңашылдық құасиеттерінің арққасында түрлі елдердің зерттеушілерінің қыызыъушылывын тудырып отыр. Оның жұмысттары үш топқ̧а бөлінеді: топологиялық эксперименттер; қовамдық және тұрвын үй құрылыстары; футуристік жобалар. Мақала вылыми жарияланымдарды зерттеу, сәулетшімен дңгімелесу, шебер мұраватынан альнван жобальқ-графикальққ құжаттар негізінде жазылган. С.Нарыновтың шыгармашылыгын талдау Қазақстанның қ̧азіргі өңірлік архитектурасындавы жаңа бавыттарды анықтаува мүмкіндік береді.

Түйін сөздер: сәулетші Сәкен Нарынов, аймақтық сәулет, Қазақ̧стан сәулеті, аймақтық бірегейлік, топологияльқ формалар.
\end{abstract}

\section{Г.С. Абдрасилова ${ }^{1}$, Л.М. Аухадиева ${ }^{*}$}

${ }^{1}$ Международная образовательная корпорация (кампус КазГАСА), Алматы, Казахстан

Информация об авторах:

Абдрасилова Гульнара Сейдахметовна - доктор архитектуры, академический профессор факультета Архитектуры, Международная образовательная корпорация (Кампус КазГАСА), Алматы, Казахстан https://orcid.org/0000-0002-3828-9220, email: g.abdrassilova@kazgasa.kz

Аухадиева Лаура Мукановна - докторант факультета Архитектуры, Международная образовательная корпорация (Кампус КазГАСА), Алматы, Казахстан

https://orcid.org/0000-0002-8834-3141, email: laukhadiyeva@gmail.com

\section{ТВОРЧЕСТВО САКЕНА НАРЫНОВА: СИМБИОЗ АРХИТЕКТУРЫ И ТОПОЛОГИЧЕСКИХ ЭКСПЕРИМЕНТОВ}

\begin{abstract}
Аннотация. Творчество казахстанского архитектора Сакена Нарынова вызывает интерес у исследователей разных стран благодаря новаторским качествам. Его работы делятся на три группы: топологические эксперименты; общественные и жилье сооружения; футуристические проекты. Статья написана на основе изучения научных публикаций, проведенных бесед с архитектором, проектно-графических документов из архива мастера. Анализ творчества С.Нарынова позволяет разработать новые подходы к пониманию языка современной архитектуры в региональных условиях Казахстана.
\end{abstract}

Ключевые слова: архитектор Сакен Нарынов, региональная архитектура, архитектура Казахстана, региональная идентичность, топологические формы. 